\title{
Editorial
}

The issue of academic status generated recurring debate at the ACRL membership meeting in Atlantic City. Although the primary debate centered on academic status, the motion as presented to the membership actually embodied two distinct issues: academic status and internal library management. Let us keep the two separate. The achievement of academic status requires the cooperation and consent of the total academic community, from the newest member of the teaching faculty to the Board of Regents. Library management, however, is not campus-wide; resolution of internal problems is primarily a library responsibility.

We should not allow any issue to detract from the matter of status. Yet why did the authors of the motion feel compelled to inject the management issue, and then defend its inclusion in a spirited floor debate? I know many colleagues who are bored, frustrated, or simply fed up with their present positions. Library school graduates are often heard to grumble that their first professional position demanded the intellectual skills of filing cards, shuffling papers, and providing such reference service as pointing the way to the nearest pencil sharpener or the "john." Exaggeration? Maybe. But let us acknowledge that many younger professionals are dissatisfied; they want more challenging positions and more opportunity for promotion.

The terms "participatory management" or "democratization of administration" are now in vogue. Participation of staff in the formulation of policy decisions is a healthy trend. But to achieve meaningful staff participation, we must begin to train young middle-management librarians for top administrative positions. Why can't we initiate a plan similar to the American Council of Education's administrative intern program? The ACRL or ALA could play a leading role. Libraries could nominate their most promising middle-level administrators to internships in leading academic libraries. Costs, including salaries, could be borne either by the participating library or by a munificent foundation. The intern would be exposed to a spectrum of problems that an administrator of an academic library might expect to encounter. He would be given an opportunity to meet and work with faculty and other non-library administrators.

Some may react negatively to a management intern program, fearing that it would produce a brain drain of promising administrators from the smaller to the larger institutions. Perhaps. But in the long run we will have provided the profession with a better prepared, more skilled leadership. 


\section{Scholarly Reprints}

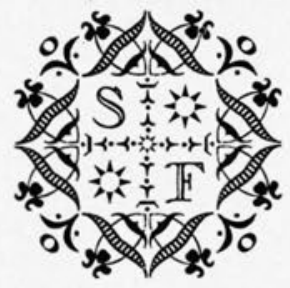

Thomas Blount. Nomolexikon: A Lawdictionary. London, 1670.

$\$ 19.00$

Edmund Fry. Pantographia.

London, I799. Illustrated.

$\$ 15.00$

Robert Greenhow. The History of

Oregon and California. Boston, 1844 .

Folding map. Index.

$\$ 12.5^{0}$

Georges Guillet de St. Georges. The Gentleman's Dictionary.

London, I705. Illustrated.

$\$ 9.00$

Christopher Irvine. Historice Scotica Nomenclatura Latino-Vernacula.

Edinburgh, $\mathbf{1 6 8 2 .}$

$\$ 12.00$

Franciscus Junius. Etymologicum Anglicanum. Edited by Edward Lye. Oxford, 1743 .
David Malcolme. Essay on the Antiquities of Great Britain and Ireland. (Expanded I5-part edition.) Edinburgh, 1738 . $\$ 12.00$

Lawson Andrew Scruggs. Women of Distinction. Raleigh, N.C., I893.

New introduction (1970) by Otey M. Scruggs, Professor of History, Syracuse University. Photographs. Illus. \$ro.00

Stephen Skinner. Etymologicon Linguce Anglicance. London, 167 I. $\$ \$ 55.00$

John Thomas Smith. Vagabondiana; or, Anecdotes of Mendicant Wanderers through the Streets of London.

London, I817. Illus. $\$ 15.00$

Silas TAYLOR. The History of Gavel-kind. London, I663. Folding chart. \$12.50

[John Worlidge]. Dictionarium Rusticum ES Urbanicum.

London, I704. Illustrated.

$\$ 27.00$

John Worlidge. Systema Agricultura. London, 1675 . The and edition. $\$ 23.00$

All books printed on acid-free "300-year" paper and bound in buckram over binder's boards. We shall be pleased to send our catalog. Address orders $\&$ inquiries to:

\section{SHERWIN $\mathcal{E} \odot$ FREUTEL Publishers}

1017 N. La cienega Boulevard Los Angeles, California 90069 [213] 652-4777 Cables: Monkbarns 